\title{
Competition for inorganic nutrients between phytoplankton and bacterioplankton in nutrient manipulated mesocosms
}

\author{
Ian Joint ${ }^{1, *}$, Peter Henriksen ${ }^{2}$, Gro Anita Fonnes ${ }^{3}$, David Bourne ${ }^{3}$, \\ T. Frede Thingstad ${ }^{3}$, Bo Riemann ${ }^{2}$

\begin{abstract}
${ }^{1}$ Plymouth Marine Laboratory, Prospect Place, The Hoe, Plymouth PL1 3DH, United Kingdom ${ }^{2}$ Department of Marine Ecology, National Environment Research Institute, PO Box 358, Roskilde 4000, Denmark

${ }^{3}$ Department of Microbiology, University of Bergen, Jahnebakken 5, 5020 Bergen, Norway
\end{abstract}

\begin{abstract}
A manipulative mesocosm experiment in Danish coastal waters tested the effect on plankton biodiversity and function of adding nitrate, phosphate and glucose. A comprehensive set of measurements was made over a $6 \mathrm{~d}$ period; these included phytoplankton biomass and production in 3 size fractions $(>10,10-2$ and $<2 \mu \mathrm{m})$, bacterial biomass and production, nitrate and ammonium uptake, and pigment taxonomy. Addition of nitrate and phosphate resulted in increases of biomass and production of all size fractions of phytoplankton. Inorganic nutrients alone had only a minor effect on bacterial abundance and production, with slight increases relative to the control. The largest changes occurred in mesocosms to which glucose was added in excess with nitrate and phosphate. Pigment composition indicated little change in phytoplankton assemblage composition in any treatment. A large increase in bacterial activity in the presence of added glucose had a negative effect on the phytoplankton assemblage and resulted in a decline in phytoplankton biomass. Data on nutrient uptake and size-fractionated carbon fixation suggest that the mechanism of this phytoplankton suppression was the ability of heterotrophic bacteria to out-compete for available inorganic nutrients, resulting in nutrient limitation of the phytoplankton assemblage.
\end{abstract}

KEY WORDS: Phytoplankton/bacterial competition · Nutrient uptake • Pigment taxonomy · Mesocosm Resale or republication not permitted without written consent of the publisher

\section{INTRODUCTION}

Planktonic diversity is the result of complex interactions which occur between different organisms in the water column. The standing stock of any organisms in an assemblage depends ultimately on a balance between growth and losses through predation, infection and sinking. It is relevant to ask which factors will have the greatest impact on biodiversity. In the case of microbial biodiversity, nutrient supply is undoubtedly an important factor which controls both standing stock

*E-mail: i.joint@pml.ac.uk of phytoplankton and also influences the overall structure of the microbial food web. In oligotrophic conditions, small phytoplankton cells dominate (Platt et al. 1983) and the microbial loop is important. When inorganic nutrients are abundant, the planktonic biomass is higher, large phytoplankton cells tend to be more abundant and mesozooplankton can be important grazers (Ryther 1969).

It has been known for many years that competition between microbial autotrophs and heterotrophs can be important (Joint \& Morris 1982) and that under conditions of limiting nutrients, heterotrophic bacteria may compete with phytoplankton for inorganic nutrients (phosphate, ammonium and nitrate). Hence, hetero- 
trophic microbes may indirectly limit primary production by depriving phytoplankton of nutrients. Nutrient availability is complex because the biomass of bacteria is controlled by protozoan grazing (Shiah \& Ducklow 1995, Thingstad \& Lignell 1997), which may recycle nutrients and result in increased nutrient availability and an enhancement of primary production (Brussaard \& Riegmann 1998).

Virus infection (Bergh et al. 1989, Proctor \& Fuhrman 1990) is another factor which may affect individual species within an assemblage. Infection is a densitydependent process since the probability that a virus will encounter its host species increases as the number of individuals of that species increases. However, the host range of viruses is narrow and infection should be considered as a more specific process than grazingalthough there is also increasing evidence of specificity in prey selection by zooplankton. The general consensus is that the grazing loss of an individual species is in proportion to its abundance within an assemblage. Virus infection is also linked to nutrient availability. Wilson \& Mann (1997) have shown how changes in phosphate concentration may induce a change from lysogenic to lytic production, resulting in the release of virus particles and increased potential for infection.

These interactions are difficult to study in the sea where dispersion adds another level of complexity and 2 methods - modelling and manipulation experiments in mesocosms - are frequently used to gain insight into these ecosystem processes. The advantages of mesocosms are now widely recognised; they provide an opportunity to constrain a planktonic assemblage, minimising dispersive losses and allow manipulations by adding nutrients (e.g. Hein \& Riemann 1995, Egge 1998, Sondergaard et al. 2000) or pollutants (Gustavson et al. 1999). Disadvantages are that dispersion is so reduced that sinking of particles will readily occur unless mechanical mixing is introduced and it may also be difficult to include the number of replicates that are common in laboratory studies.

Previous attempts have been made to alter the balance between autotrophy and heterotrophy. However, results obtained when adding an organic carbon source, such as glucose, to mesocosms are contradictory since there are reports both of a shift towards a heterotrophic assemblage after glucose addition (Parsons et al. 1981) and reports with no significant effects from adding glucose alone (Thingstad et al. 1999b). This apparent conflict may be resolved if the natural system can have 2 states, characterised by either carbon or inorganic nutrient limitation of bacterial growth. Analysis of dynamic systems with different states is difficult without the aid of mathematical models, and models are routinely used to investigate trophic interactions in relation to nutrient limitation (e.g. Taylor \& Joint 1990, Baretta-Bekker et al. 1998, Thingstad et al. 1999a,b). They also provide an important structure within which a mesocosm experiment can be designed and implemented. This study uses that approach and a model (Thingstad unpubl.) was used to interpret the results described here.

In this experiment, we manipulated inorganic (nitrate, phosphate and silicate) and organic (glucose) nutrient concentrations in order to study the response of phytoplankton and bacterial communities. This paper reports how phytoplankton and bacterial activity reacted; changes in biodiversity within the bacterial and viral communities will be reported elsewhere (Øvreås et al. unpubl.). A series of 12 mesocosms was set up in May 2000 in Danish coastal waters and involved the addition of nitrate and phosphate at 2 different rates and in 2 ratios, the addition of nitrate, phosphate and glucose at 2 rates, and the addition of nitrate, phosphate and silicate at 2 rates. The experimental design aimed to induce a shift to a diatomdominated population by adding silicate since it was assumed that in May, the water could be silicatedeplete. A change in the heterotroph/autotroph balance was hoped for by the addition of glucose, with the primary aim of investigating how microbial biodiversity responded to these manipulations.

\section{MATERIALS AND METHODS}

Study site. The experiments were done from 20 to 31 May 2000 at the Søminestationen, Holbæk, a research facility of the University of Roskilde. A pontoon was anchored $\sim 100 \mathrm{~m}$ offshore in Isefjorden and 12 mesocosms of $1.7 \mathrm{~m}^{3}$ capacity were suspended in a linear array from the pontoon. The experimental mesocosms were constructed from reinforced polyethylene sea curtain and the design minimised shading effects. Mesocosms were filled on the evening of 20 May (Day 0 ) by submersing the collapsed bag in the fjord and slowly lifting the supporting ring at the top of the enclosure to contain a body of water. It took $\sim 2 \mathrm{~h}$ to fill all 12 mesocosms, but in this region of small tides and with little wind mixing on 20 May, it was assumed that there was a high degree of homogeneity between the mesocosms. No differences were detected in chlorophyll (chl a) concentration or phosphate and silicate concentrations when the mesocosms were first sampled $12 \mathrm{~h}$ after they were filled (Day 1). Mixing of the water in the mesocosms was achieved by air-lifting water from the bottom to the top of the bags through a tube into which air was injected at the mid-depth. Integrated samples of the whole water column were collected using a plexiglass tube. 
Experimental design. Inorganic nutrients were added as nitrate $\left(\mathrm{NaNO}_{3}\right)$, phosphate $\left(\mathrm{NaH}_{2} \mathrm{PO}_{4}\right)$, silicate $\left(\mathrm{Na}_{2} \mathrm{SiO}_{3}\right)$ and glucose was the source of labile DOC (Table 1). The central mesocosm in the line (Mesocosm 5) acted as a control and no additions were made to this water. Mesocosms 1 and 2 were supplemented with nitrate and phosphate in an N:P ratio of 16:1 (Redfield et al. 1963). The addition to Mesocosm 2 $\left(1.6 \mu \mathrm{mol} \mathrm{N} l^{-1} \mathrm{~d}^{-1}\right.$ and $\left.0.1 \mu \mathrm{mol} \mathrm{P} \mathrm{l}{ }^{-1} \mathrm{~d}^{-1}\right)$ was twice the rate added to Mesocosm 1. Mesocosms 3 and 4 were designed to induce a shift to nitrogen limitation and nutrients were added at an $\mathrm{N}: \mathrm{P}$ ratio of $4: 1$, again at 2 rates of addition (Table 1). Mesocosms 6 and 7 had additions at an N:P ratio of 64:1 with the aim of shifting to phosphate limitation.

In Mesocosms 8 and 9, nitrate and phosphate were added in the Redfield ratio and at the same rates as in Mesocosms 1 and 2. In addition, glucose was added at

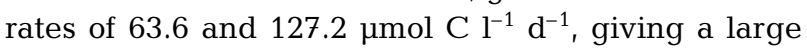
excess of carbon with added C:N:P ratios of 1272:16:1 in both Mesocosms 8 and 9. Mesocosms 10 and 11 had nitrate and phosphate added at rates identical to those in Mesocosms 1 and 2 and, in addition, silicate was added to give an N:P:Si ratio of 16:1:16 (i.e. 0.8 and $1.6 \mu \mathrm{mol} \mathrm{Si} \mathrm{l}^{-1} \mathrm{~d}^{-1}$, respectively) in order to determine if the diatom assemblage was silicate limited.

In the event, fewer changes occurred in the phytoplankton assemblage than were expected and a diatom bloom was not induced in Mesocosms 10 and 11. As a consequence, this paper will concentrate on the results obtained in 5 mesocosms - the control, Mesocosms 1 and 2 with nitrate and phosphate added in the Redfield ratio, and Mesocosms 8 and 9 with added glucose as well as nitrate, phosphate in the Redfield ratio. The initial plan involved a $10 \mathrm{~d}$ experiment; however, after 6 d (27 May), a severe storm damaged the mesocosms and allowed exchange of water between the mesocosms and the fjord. The results are reported for a $6 \mathrm{~d}$ experimental period only.

Chemical analysis. Nitrate and ammonium concentrations were determined as soon as was practicable after sampling, which was always within $3 \mathrm{~h}$ of sample collection. In the period between sampling and analy- sis, samples were stored in a refrigerator in the dark. Nutrient concentrations were determined using manual colorimetric methods based on Brewer \& Riley (1965) for nitrate, Grasshoff (1976) for nitrite, and Mantoura \& Woodward (1983) for ammonium. Silicate and phosphate concentrations were determined by colorimetric methods according to Mullin \& Riley (1966) and Strickland \& Parsons (1968), respectively. Care was taken to establish reagent and sample blanks, and the accuracy of nutrient determination was established by standard additions of nitrate, nitrite or ammonium to each sample. DOC was measured by high-temperature catalytic oxidation using a Shimadzu TOC-5000 analyser. Prior to analysis, samples were filtered on acid-washed Gelman Supor-200 filters $(0.2 \mu \mathrm{m}$ nominal pore size), acidified and bubbled to remove inorganic carbon. Standard curves were prepared with potassium hydrogen phthalate.

Pigment analysis and determination of phytoplankton assemblage structure. Phytoplankton pigments were analysed in 2 ways: (1) by fluorometry of acetone extracts of size-fractionated phytoplankton (Joint \& Pomroy 1983); and (2) by HLPC determination according to the method of Wright et al. (1991) with minor modifications as described in Schlüter \& Havskum (1997). Water samples were kept in the dark and filtered generally within $3 \mathrm{~h}$ of sampling. For fluorometric determination, $100 \mathrm{ml}$ samples were filtered sequentially through 10,2 and $0.2 \mu \mathrm{m}$ pore size polycarbonate filters which were immediately frozen. Pigments were extracted overnight at $4{ }^{\circ} \mathrm{C}$ with $90 \%$ acetone and chl a concentration was determined by the method of Holm-Hansen et al. (1965).

Analysis of the total pigment complement was by HPLC. Samples (100 to $300 \mathrm{ml})$ were filtered onto $25 \mathrm{~mm}$ Advantec GF 75 glass fibre filters (Toyo Roshi Kaisha) and stored in liquid nitrogen. For extraction of pigments, filters were transferred to $3 \mathrm{ml}$ acetone, sonicated on ice for $15 \mathrm{~min}$, and left for $24 \mathrm{~h}$ at $4^{\circ} \mathrm{C}$. Subsequently, $1 \mathrm{ml}$ of extract was filtered $(0.2 \mu \mathrm{m}$ pore size filters) and mixed with $300 \mu \mathrm{l}$ water. HPLC analyses were performed on a Shimazu LC 10A system with a Supercosil C18 column $(250 \times 4.6 \mathrm{~mm} \times 5 \mu \mathrm{m})$. Pig-

Table 1. Experimental design. No additions were made to the control mesocosm and nitrate, phosphate and glucose were added to the other mesocosms in the ratios and rates indicated

\begin{tabular}{|c|c|c|c|c|}
\hline Mesocosm & & 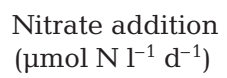 & $\begin{array}{l}\text { Phosphate addition } \\
\quad\left(\mu \mathrm{mol} \mathrm{P} \mathrm{l}^{-1} \mathrm{~d}^{-1}\right)\end{array}$ & 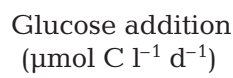 \\
\hline 5 & No addition & 0 & 0 & 0 \\
\hline 1 & $\mathrm{~N}: \mathrm{P}=16: 1$ & 0.80 & 0.05 & 0 \\
\hline 2 & $\mathrm{~N}: \mathrm{P}=16: 1$ & 1.60 & 0.10 & 0 \\
\hline 8 & $\mathrm{C}: \mathrm{N}: \mathrm{P}=1272: 16: 1$ & 0.80 & 0.05 & 63.60 \\
\hline 9 & $\mathrm{C}: \mathrm{N}: \mathrm{P}=1272: 16: 1$ & 1.60 & 0.10 & 127.20 \\
\hline
\end{tabular}


ments were identified from retention times and by comparison of absorption spectra with to those of authentic standards, purchased from the International Agency for ${ }^{14} \mathrm{C}$ Determination.

Phytoplankton assemblage composition was calculated from pigment signatures using the matrix factorisation program CHEMTAX (Mackey et al. 1996). Pigment ratios derived from laboratory cultures of coastal species representing 6 classes of phytoplankton (Henriksen et al. 2002) were used in the input ratio file for the CHEMTAX calculations. These classes of phytoplankton (dinoflagellates, diatoms, cryptophytes, haptophytes, chlorophytes and prasinophytes) were chosen because their presence was indicated from the pigments identified by HPLC.

Identification of phytoplankton species by microscopy was used to compare with the phytoplankton assemblage structure characterised from pigments. The initial phytoplankton assemblage in the control mesocosm was determined by microscopy according to Utermöhl (1958). Phytoplankton carbon biomass was calculated from cell counts and dimension measurements assuming simple geometric shapes and applying conversion factors of $0.13 \mathrm{pg} \mathrm{C} \mathrm{mm}^{-3}$ for thecate dinoflagellates and $0.11 \mathrm{pg} \mathrm{C} \mathrm{mm}^{-3}$ for other phytoplankton groups. Carbon content of diatoms was corrected for the reduced $\mathrm{C}$ content of cell vacuoles (pg $\mathrm{C}$ $\left[\mu \mathrm{m}^{3}\right.$ vacuole $^{-1}=0.1 \times \operatorname{pg~C}\left[\mu^{3} \text { plasma volume }\right]^{-1}$ ) according to Edler (1979).

Primary production determination. Rates of carbon fixation were estimated from the incorporation of ${ }^{14} \mathrm{C}$ bicarbonate. Water samples were collected at dawn from each mesocosm and were transferred into five $60 \mathrm{ml}$ clear, and one black, polycarbonate bottles; all bottles were cleaned following JGOFS protocols (IOC 1994) to reduce trace metal contamination. Each bottle was inoculated with $370 \mathrm{kBq}(10 \mu \mathrm{Ci}) \mathrm{NaH}^{14} \mathrm{CO}_{3}$ (supplied by the International Agency for ${ }^{14} \mathrm{C}$ Determination) and incubated in situ in the mesocosms for $24 \mathrm{~h}$. Bottles were attached to a fine cord and held in the centre of each mesocosm at the following depths: immediately below the water surface, at $0.5,1.0,1.5$ and $2.0 \mathrm{~m}$. The dark bottle was suspended at the middepth of the mesocosm at $1 \mathrm{~m}$. At dawn the following day, bottles were removed from the mesocosms and kept in the dark until filtered; all samples were usually filtered within $3 \mathrm{~h}$ of the end of the incubation.

At the end of the incubation period, each sample was filtered sequentially through 10, 2 and $0.2 \mu \mathrm{m}$ pore size polycarbonate filters (Joint \& Pomroy 1983). The filters were fumed in $\mathrm{HCl}$ for $30 \mathrm{~min}$, dried and stored in a desiccator. Samples were counted on return to the laboratory in Plymouth in a liquid scintillation counter (LSC), the efficiency of which was determined with an external standard, channels ratio method. The quantity of ${ }^{14} \mathrm{C}$ added to the experimental bottles was determined by adding aliquots of the stock ${ }^{14} \mathrm{C}$ solution to a $\mathrm{CO}_{2}$-absorbing scintillation cocktail, which was counted in the LSC. Alkalinity was determined in each mesocosm on 2 occasions during the experiment; however, no changes with time were detectable.

Nitrate and ammonium uptake. Rates of nitrate and ammonium uptake were determined by inoculating water samples with the stable isotope ${ }^{15} \mathrm{~N}$ (Rees et al. 1999). Samples from each mesocosm were distributed into $640 \mathrm{ml}$ clear polycarbonate bottles, and ${ }^{15} \mathrm{~N}-\mathrm{NO}_{3}{ }^{-}$ and ${ }^{15} \mathrm{~N}_{-} \mathrm{NH}_{4}{ }^{+}$were added at $0.5 \mu \mathrm{mol} \mathrm{l^{-1 }}$. Duplicate samples in clear and dark bottles were incubated in situ with each tracer for $24 \mathrm{~h}$ at a depth of $1 \mathrm{~m}$ in each mesocosm. The incubation period was identical to that of the primary production experiments. After $24 \mathrm{~h}$, samples were filtered through ashed Whatman GF/F filters. The GF/F filters were washed with filtered sea water and stored frozen until analysis in Plymouth. Filters were oven-dried at $50^{\circ} \mathrm{C}$ before analysis. Particulate nitrogen and atom $\%{ }^{15} \mathrm{~N}$ was measured by continuous flow nitrogen analysis-mass spectrometry (Europa Scientific) using the techniques described by Owens \& Rees (1989). Rates of assimilation were calculated from the equations of Dugdale \& Goering (1967).

Bacterial abundance, production and tests for nutrient limitation. DAPI (4', 6-diamidino-2-phenylindole) staining was used to estimate total bacterial numbers in the mesocosms. Water samples (1 to $5 \mathrm{ml}$ ) were filtered onto black $0.2 \mu \mathrm{m}$ pore size black polycarbonate filters (Poretics), stained with DAPI solution $\left(1 \mu \mathrm{g} \mathrm{ml}^{-1}\right)$ for $10 \mathrm{~min}$ and washed with filtered sterile water (Porter \& Feig 1980). Filters were mounted in paraffin oil and counts determined with a Zeiss Axioplan epifluorescence microscope (Oberkochen) fitted with a $50 \mathrm{~W}$ high pressure mercury bulb and specific DAPI filter set (DAPI-Zeiss 01). More than 2000 cells were counted on replicate filters for each sample.

Bacterial production was estimated from the incorporation of ${ }^{3} \mathrm{H}$ thymidine and ${ }^{14} \mathrm{C}$ leucine (Amersham Pharmacia Biotech). ${ }^{3} \mathrm{H}$ thymidine $\left(10 \mathrm{nmol}^{-1}\right)$ and ${ }^{14} \mathrm{C}$ leucine $\left(50 \mathrm{nmol} \mathrm{l}^{-1}\right)$ were added to the same $10 \mathrm{ml}$ water sample, which was incubated in $20 \mathrm{ml}$ glass vials for $1 \mathrm{~h}$. The incubation was ended by the addition of $500 \mu \mathrm{l} 100 \%$ TCA; blanks were prepared by adding $500 \mu 100 \%$ TCA to sea water samples prior to the addition of isotopes. Samples were filtered through $0.45 \mu \mathrm{m}$ Sartorius cellulose nitrate filters, rinsed with ice cold $5 \%$ TCA and counted in a liquid scintillation counter with $10 \mathrm{ml}$ Ultima gold (Packard) scintillation cocktail. Bacterial carbon production was calculated

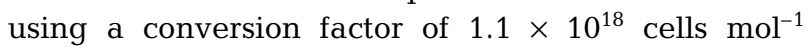
thymidine incorporated (Riemann et al. 1987). Thymidine incorporation was converted to cell production using a constant biomass per cell of $20 \mathrm{fg}$ C. Leucine 
incorporation into protein was estimated according to Simon \& Azam (1989).

At the beginning of the experiment and after $3 \mathrm{~d}$, bioassays were done to determine which nutrient might have been limiting bacterial growth. Glucose, ammonium and phosphate were added to triplicate $20 \mathrm{ml}$ samples in acid-rinsed scintillation vials to give

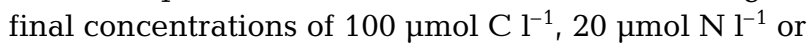
$1 \mu \mathrm{mol} \mathrm{P}^{-1}$, alone or in all possible combinations. Triplicate vials without additions served as a control. Bacterial production was measured $18 \mathrm{~h}$ after substrate addition by ${ }^{3} \mathrm{H}$ leucine incorporation using the method of Smith \& Azam (1992).

\section{RESULTS}

\section{Nutrient concentrations}

Throughout the experiment, samples were taken in the fjord adjacent to the mesocosms to test how similar the plankton assemblages in the mesocosms were to those in the fjord. During the period of the experiment, there was considerable wind-driven water movement which, in this microtidal region with tides of the order of $\mathrm{cm}$, resulted in changes in water height of $>0.5 \mathrm{~m}$. It is likely that there was considerable wind-driven mixing and exchange in the fjord which make comparisons difficult between the mesocosms and the fjord. Therefore, responses to the manipulations are compared to the unmodified mesocosm (Mesocosm 5) rather than to the fjord.

Although no significant changes occurred in plankton biomass in the control mesocosm, some minor temporal variations were recorded during the experiment. A very small increase in nitrate concentration was detected in the control mesocosm during the period from 21 to 26 May, with concentrations increasing from 0.3 to $0.4 \mu \mathrm{mol} \mathrm{N}{ }^{-1}$ (Fig. 1a). Over the same period, ammonium concentrations also increased slightly from 0.2 to $0.7 \mu \mathrm{mol} \mathrm{N}{ }^{-1}$ (Fig. 1b). Phosphate also varied, particularly on the last $2 \mathrm{~d}$ when concentrations

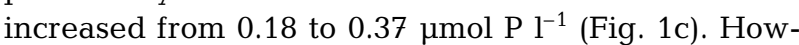
ever, the largest change in the control mesocosm was
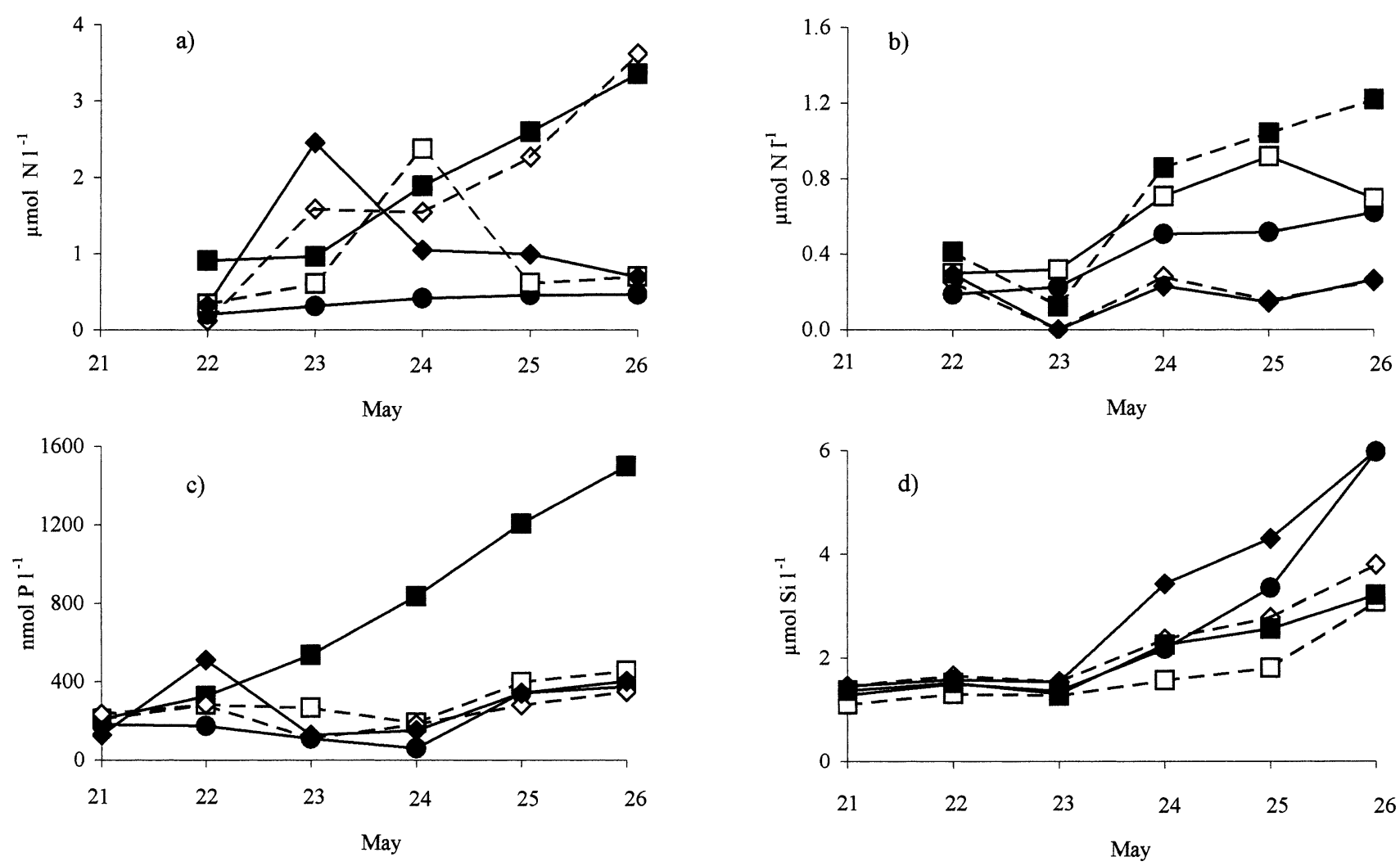

Fig. 1. Nutrient concentrations measured at dawn (04:45 to 05:15 h) each day. Nutrient additions were made at dusk (20:00 to 21:00 h) each evening so these values represent the nutrient concentrations $\sim 8 \mathrm{~h}$ after addition. (a) Nitrate, (b) ammonium, (c) phosphate and (d) silicate concentration in (@) Mesocosm 5 (control), ( $\square$ ) Mesocosm 1, which was supplied with nitrate and

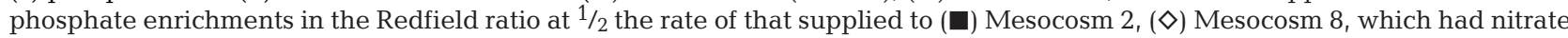
and phosphate supplied in the same ratio and rate as Mesocosm 1 but with the addition of glucose, and ( $\bullet$ ) Mesocosm 9 which had nitrate, phosphate and glucose added in the same ratios as Mesocosm 8 but at twice the rate 


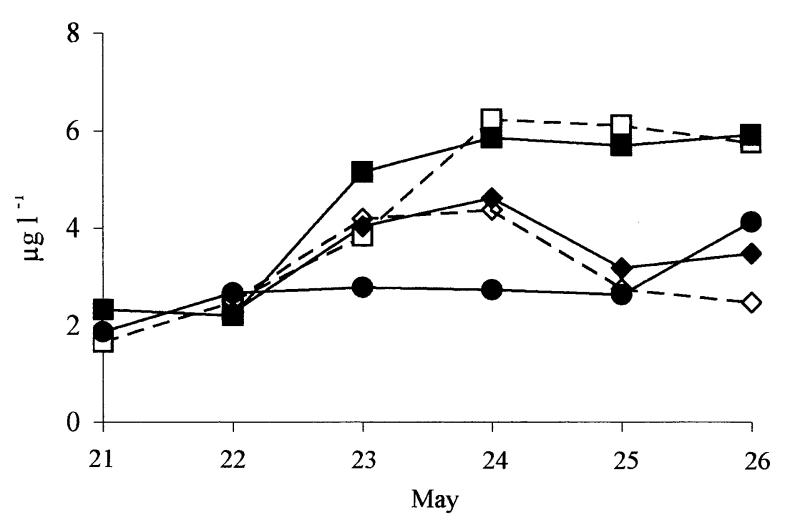

Fig. 2. Total chlorophyll concentration in each mesocosm determined at dawn each day by fluorometry in (0) Mesocosm 5 (control), ( $\square$ ) Mesocosm 1 with nitrate and phosphate additions at the lower rate, (ם) Mesocosm 2 with nitrate and phosphate additions at the higher rate $(\diamond)$ Mesocosm 8 with nitrate, phosphate and glucose additions at the lower rate, and $(\diamond)$ Mesocosm 9 with nitrate, phosphate and glucose additions at the higher rate

in silicate concentration (Fig. 1d), which increased from 1.3 to $5.9 \mu \mathrm{mol} \mathrm{Si}{ }^{-1}$. These changes provide the background against which the nutrient addition experiments can be judged. Although changes in the control mesocosm were insignificant in comparison to the concentrations of added nutrients, they do suggest that considerable heterotrophic activity was occurring in unmodified fjordic water at the time of the experiment. Total dissolved nitrogen (nitrate and ammonium) and phosphate increases would be consistent with mineralisation of organic matter and the silicate increase in particular suggests that an accumulation of diatomderived material was being remineralised.

The accumulation of nitrate in the experimental mesocosms was significantly less than would be expected if there was no biological utilisation of the added nitrate. For example, Mesocosm 2 shows the most consistent increments in nitrate concentration through the

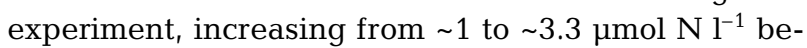
tween Days 3 and 6. Over the same $3 \mathrm{~d}$ period, $4.8 \mu \mathrm{mol}$ $\mathrm{N}^{-1}$ of nitrate was added so if there was no biological nitrate utilisation, the nitrate concentration on Day 6 would be expected to be at least $5.8 \mu \mathrm{mol} \mathrm{N} \mathrm{^{-1 }}$. It is interesting that there were large increases in nitrate concentration between Days 2 and 3 in those mesocosms to which glucose was added, but that concentrations subsequently declined; this would be consistent with the development of a heterotrophic assemblage which was utilising the added glucose as its carbon source and assimilating nitrate as nitrogen source. No accumulation of ammonium occurred in the 2 mesocosms with added glucose (Fig. 1b); however, ammonium did increase in concentration in the mesocosms with added $\mathrm{N}$ and $\mathrm{P}$ but with no added carbon source. Again, this observation would be consistent with a heterotrophic assemblage in Mesocosms 8 and 9, which had excess carbon source, enabling them to utilise all the available nitrate and ammonium.

The phosphate concentration in Mesocosm 2 (high rate of $\mathrm{N}$ and $\mathrm{P}$ addition) increased at a greater rate than the addition of phosphate (which was at $100 \mathrm{nmol}$ $\mathrm{P}^{-1} \mathrm{~d}^{-1}$ ). Similar increases were measured in Mesocosms 3 and 4, which had additions skewed towards N-limitation (results not shown). The source of this phosphate is not known but there was no evidence of seabird activity near the mesocosms; therefore, bird excrement is an unlikely source of phosphate in these systems.

In the mesocosms not receiving glucose, DOC remained constant at a concentration of $330 \pm 20 \mu \mathrm{mol}$ $\mathrm{C}^{-1}$, while in the Mesocosms 8 and 9, it increased to 790 and $1052 \mu \mathrm{mol} \mathrm{Cl^{-1 }}$ on 26 May (Day 5), confirming that glucose was added at a rate much greater than the consumption rate by the microbial assemblages.

\section{Phytoplankton biomass and assemblage composition}

There was little change in phytoplankton biomass in the control mesocosm (Mesocosm 5) during the experimental period (Fig. 2). Chl a concentration initially increased in those mesocosms to which $\mathrm{N}$ and $\mathrm{P}$ were added (Mesocosms 1 and 2). In the mesocosms receiving glucose as well as $\mathrm{N}$ and $\mathrm{P}$ (Mesocosms 8 and 9), there were initial increases in biomass similar to those in Mesocosms 1 and 2, but pigments subsequently declined to the concentration in the control mesocosm.

Fig. 3 shows the chl a concentration in 3 size fractions-the picoplankton $(<2 \mu \mathrm{m}$ cells $)$, small nano-

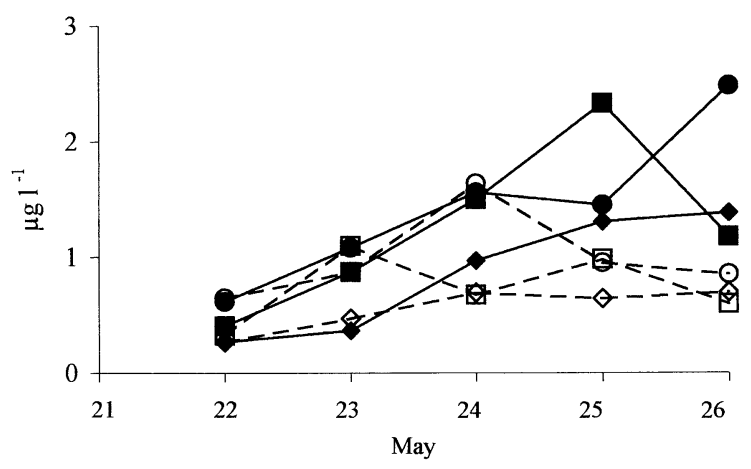

Fig. 3. Chlorophyll concentration $\left(\mu \mathrm{g}^{-1}\right)$ in 3 size fractions of phytoplankton. $(\bullet)>10 \mu \mathrm{m},(\mathbb{\square}) 10-2 \mu \mathrm{m},(\bullet)<2 \mu \mathrm{m}$ size fractions in Mesocosm 1, which received nitrate and phosphate additions at the lower rate and $(\diamond)>10 \mu \mathrm{m},(\square)$ 10-2 $\mu \mathrm{m},(\mathrm{O})$ $<2 \mu \mathrm{m}$ size fractions in Mesocosm 8, which received nitrate, phosphate and glucose at the lower rate 


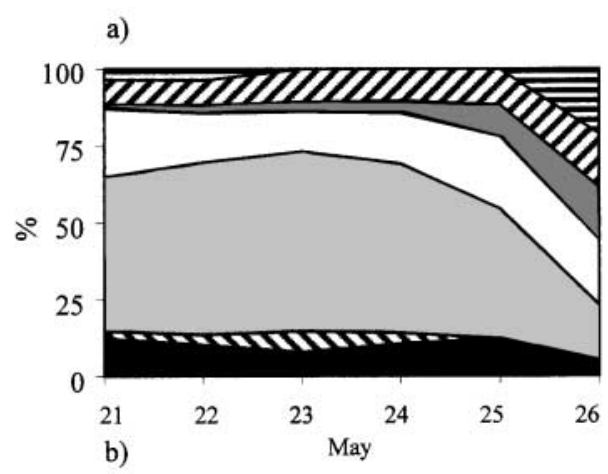

\section{日Euglenophyceae \\ \Prasinophyceae 2 \\ $\square$ Prasinophyceae 1 \\ $\square$ Cryptophyceae \\ $\square$ Bacillariophyceae \\ \Prymnesiophceae \\ Dinophyceae \\ c)}

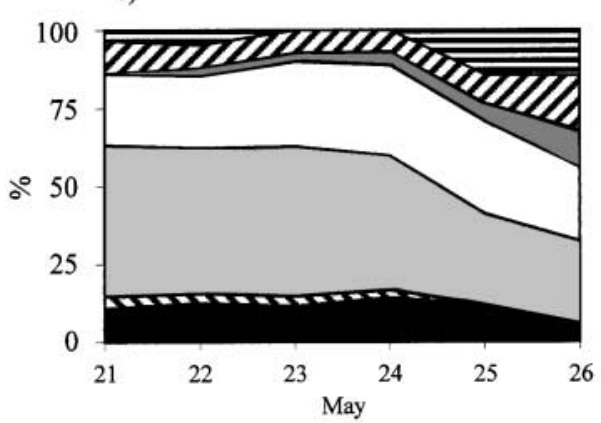

Fig. 4. Major phytoplankton taxa present in 3 mesocosms during the experiment. The contribution of each group to the total chlorophyll is based on HPLC pigment determination. Prasinophytes 1 and Prasinophytes 2 represent prasinophytes with and without prasinoxanthin, respectively. (a) Changes in phytoplankton composition in Mesocosm 5 (control). (b) Mesocosm 2 with nitrate and phosphate additions at the higher rate. (c) Mesocosm 9 with nitrate, phosphate and glucose additions at the higher rate

plankton $(10-2 \mu \mathrm{m}$ cells) and phytoplankton $>10 \mu \mathrm{m}-$ in 2 directly comparable mesocosms. Mesocosm 1 had $\mathrm{N}$ and $\mathrm{P}$ added at the lower rate and Mesocosm 8 had $\mathrm{N}$ and $\mathrm{P}$ added at the same rate but was also supplemented with glucose. In the absence of glucose, there was a net increase in chl a concentration in all 3 size fractions. The most rapid increase was in the $>10 \mu \mathrm{m}$ fraction, with a decrease in the 10-2 $\mu$ m fraction on the last day. In the mesocosm to which glucose was added, picoplankton was the only fraction which showed any net increase in chl a concentration, and then only until Day 4 ; after which, chl $a$ in the $<2 \mu \mathrm{m}$ fraction declined rapidly. It is interesting that only the picophytoplankton fraction was able to increase in abundance when glucose was present and that even this slight stimulation lasted for only $2 \mathrm{~d}$.

Phytoplankton assemblage composition, based on pigment composition and CHEMTAX analysis, indicated that the assemblage was dominated by diatoms (Fig. 4), which accounted for about $\frac{1}{2}$ of the chl a biomass; cryptophytes were the next most abundant group. Dinoflagellates were the third most significant part of the assemblage and these 3 groups comprised $>75 \%$ of the chl a content. However, microscopebased analysis of the initial phytoplankton assemblage in the control mesocosm did not indicate high diatom abundance (Fig. 5). Diatoms constituted $<10 \%$ of the phytoplankton biomass identifiable by microscope analysis and approximately $40 \%$ of the biomass was composed of unidentified non-diatom phytoplankton $<10 \mu \mathrm{m}$. Dinoflagellates and the autotrophic ciliate Myrionecta rubra (Mesodinium rubrum) were the dominant groups of identifiable organisms, each representing ca. $20 \%$ of the total biomass.

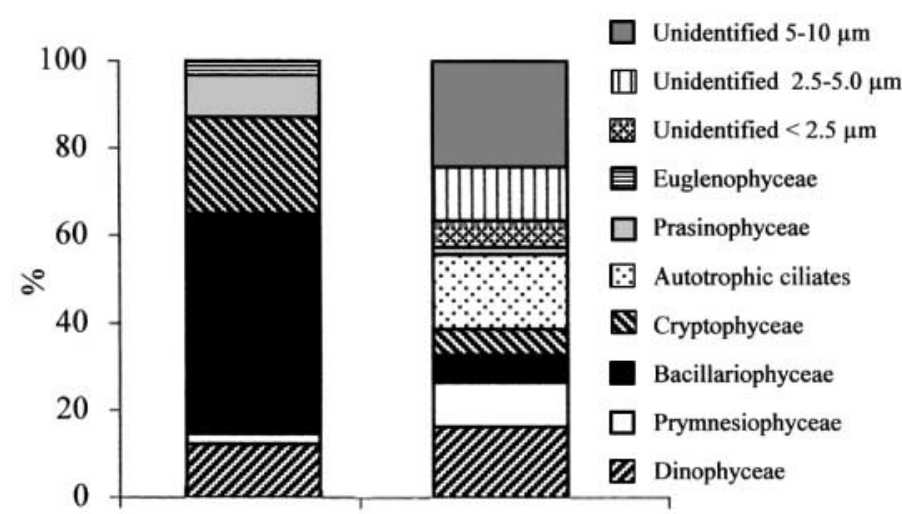

Pigment- based Microscope-based

Fig. 5. Comparison of HPLC and microscopy determinations of major phytoplankton taxa at the beginning of the experiment in Mesocosm 5 (control) 


\section{Primary production}

The chl a data (Fig. 2) suggest that there was little variability in phytoplankton biomass in the control mesocosm over the experimental period. Primary production rate was also very constant over this time. Fig. 6 shows depth-integrated production (from the

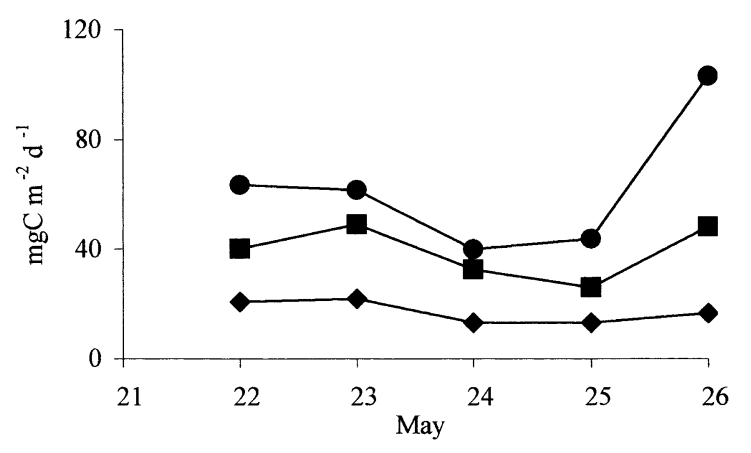

Fig. 6. Primary production rate $\left(\mathrm{mg} \mathrm{C} \mathrm{m}^{-2} \mathrm{~d}^{-1}\right)$ of 3 size fractions of phytoplankton in Mesocosm 5 (control). $(\diamond)>10 \mu \mathrm{m}$,

(ロ) 10-2 $\mu \mathrm{m},(\bullet)<2 \mu \mathrm{m}$ size fractions
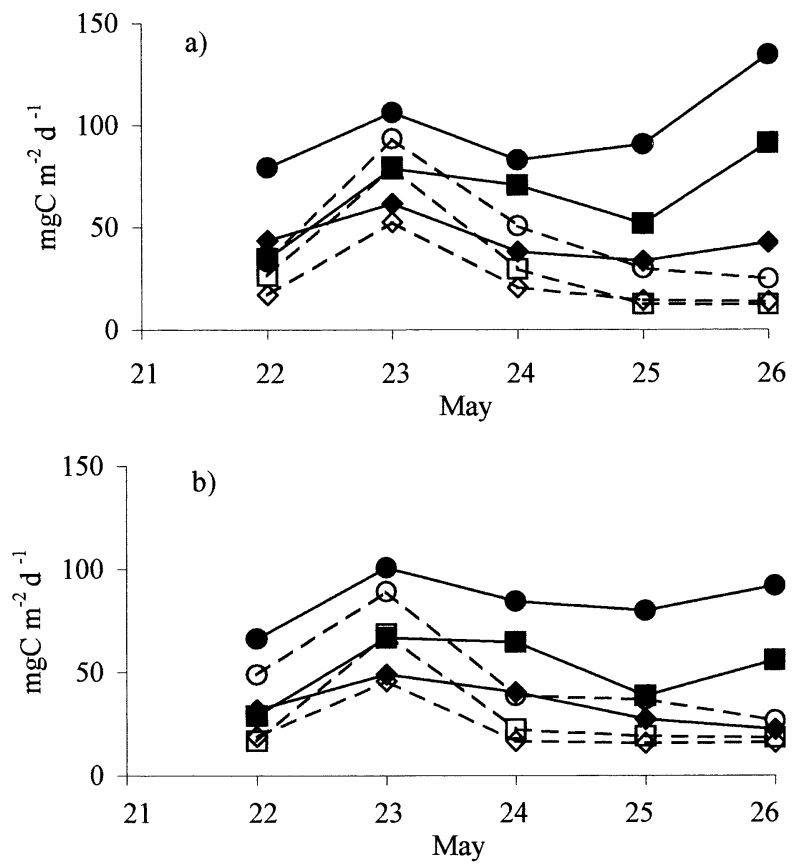

Fig. 7. Size fractionated primary production determined in mesocosms supplied with nutrient additions at (a) the lower rate (Mesocosms 1 and 8 ) and (b) higher rate (Mesocosms 2 and 9). ( $)>10 \mu \mathrm{m},(\mathbb{\square}) 10-2 \mu \mathrm{m},(\bullet)<2 \mu \mathrm{m}$ size fractions in Mesocosms 1 and 2, which received nitrate and phosphate additions, and $(\diamond)>10 \mu \mathrm{m},(\square) 10$ to $2 \mu \mathrm{m},(O)<2 \mu \mathrm{m}$ size fractions in Mesocosms 8 and 9, which received nitrate, phosphate and glucose surface to the base of the mesocosm) in the control mesocosm. Picoplankton was the most active fraction and there was little change in carbon fixation rates until Day 6 when the picoplankton significantly increased in activity; there was also a slight increase in the 10-2 $\mu \mathrm{m}$ fraction, which followed a decline on Day 5.

In the nutrient manipulation mesocosms, picoplankton continued to be the most active fraction. Fig. 7 shows the effect of the glucose addition on primary production. Fig. 7a compares carbon fixation in Mesocosms 1 and 8; both mesocosms received the same $\mathrm{N}$ and $\mathrm{P}$ but Mesocosm 8 also received added glucose. Fig. 7b compares Mesocosms 2 and 9, which received $\mathrm{N}$ and $\mathrm{P}$ at the same ratio as Mesocosms 1 and 2 but at double the rate; Mesocosm 9 was also supplemented with glucose. The addition of $\mathrm{N}$ and $\mathrm{P}$ resulted in increased primary production rates in all size fractions; however, since chl a concentration also increased, there was little change in the chl a-specific rate of carbon fixation. The most significant effect was the reduction in carbon fixation rate in those mesocosms to which glucose was added. In both Mesocosms 8 and 9, there was an initial increase in carbon fixation rates in all 3 size fractions between Days 2 and 3; thereafter, carbon fixation rates declined.

\section{Nitrate and ammonium uptake}

Nitrate and ammonium uptake were measured at only 1 depth in each mesocosm and samples were not size fractionated. Therefore, estimates are only available for the activity of the whole assemblage; it also was not possible to distinguish between autotrophic and heterotrophic activity. Fig. 8a shows the rates of nitrate uptake measured in each mesocosm. As with carbon fixation, there was little variation in nitrate uptake in the control mesocosm. On Day 3, elevated rates were measured in both mesocosms that had low rates of nutrient supply (Mesocosms 1 and 8) but nitrate uptake rate declined on subsequent days. The rates of nitrate uptake in the mesocosms with high rates of supply were not significantly different from those measured in the control mesocosm.

In the control, ammonium uptake (Fig. 8b) was slightly higher than nitrate uptake. In the other mesocosms, ammonium uptake was slightly higher than nitrate and generally ammonium appeared to be the more important nitrogen source. This is interesting because nitrogen was supplied to the mesocosms as $\mathrm{NaNO}_{3}$ and nitrate uptake rates were expected to be the more significant.

Since carbon fixation was measured at the same depth and for the same time as nitrate and ammonium uptake rates were determined, it is possible to calcu- 
late C:N uptake ratios - at least at a depth of $1 \mathrm{~m}$ in each mesocosm. The estimates are shown in Table 2. There was some variation in $\mathrm{C}: \mathrm{N}$ uptake ratio in the control mesocosm but generally they were close to the Redfield ratio of 6.6. For the first $2 \mathrm{~d}$ of the experiment, the C:N uptake ratios in the other 4 mesocosms were also very close to the Redfield ratio; in both low addition rate mesocosms (Mesocosms 1 and 8) the C:N uptake ratios were higher on Day 2. By Day 3, there was considerable divergence in the $\mathrm{C}: \mathrm{N}$ uptake ratios.

In the mesocosms without added glucose, higher $\mathrm{C}: \mathrm{N}$ uptake ratios were measured. In Mesocosm 1, the ratio increased from 6.5 on Day 3 to 14.1 on Day 6 . In Mesocosm 2, the ratio increased to 10.3 on Day 4 and remained at about that level until the end of the experiment. These high C:N uptake ratios suggest that the phytoplankton was fixing more carbon than would be required to maintain the Redfield ratio of the developing assemblage. In contrast, the C:N uptake ratio declined in the 2 mesocosms to which glucose was added. This ratio is derived from the carbon fixation rate measured with ${ }^{14} \mathrm{C}$ in the light. If, as we suspect, the glucose had stimulated the activity of the heterotrophic microbial assemblage, the $\mathrm{C}: \mathrm{N}$ uptake ratio would be expected to decline. A proportion of the nitrate and ammonium uptake must have been by heterotrophic bacteria which were utilising the added glucose. Since we cannot distinguish autotrophic from heterotrophic nitrogen assimilation, and since both would be measured in these experiments, a decline in $\mathrm{C}: \mathrm{N}$ uptake ratio is consistent with the presence of an active heterotrophic assemblage utilising DOC as carbon source.

\section{Bacterial biomass and production}

There was a slight tendency towards increased bacterial production, measured as leucine or thymidine incorporation, in Mesocosms 1 and 2, which received inorganic nutrients (Fig. 9). This led to a small, but consistent, net increase in bacterial abundance in Mesocosms 1 and 2 relative to the control
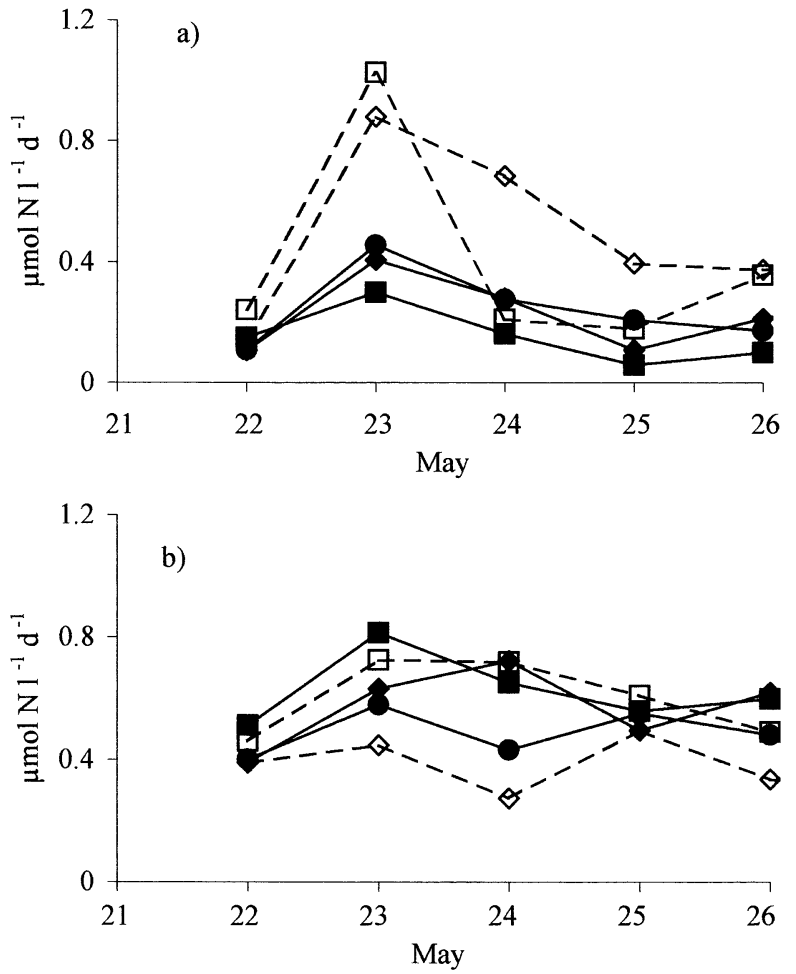

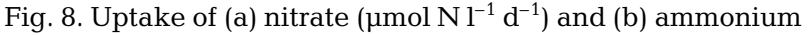

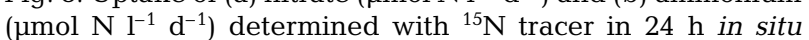
incubations at $1 \mathrm{~m}$ depth in the mesocosms. (@) Mesocosm 5 (control) with no nutrient additions, $(\square)$ Mesocosm 1 to which nitrate and phosphate were added at the lower rate, (ם) Mesocosm 2 to which nitrate and phosphate were added at the higher rate, $(\diamond)$ Mesocosm 8 to which nitrate, phosphate and glucose were added at the lower rate, and $(\diamond)$ Mesocosm 9, nitrate, phosphate and glucose at the higher rate

(Mesocosm 5) (Fig. 10). The addition of glucose together with inorganic nutrients had a very marked stimulatory effect on both production (Fig. 9) and abundance in Mesocosms 8 and 9 (Fig. 10). The dominant bacteria in Mesocosms 8 and 9 were Vibrio species (Øvreås et al. unpubl.) which were large cells. Therefore, the data on cell numbers in Fig. 10 do not give a true indication of the increase in bacterial biomass that resulted from the addition of glucose.

Table 2. C:N uptake ratio measured at $1 \mathrm{~m}$ depth in each mesocosm. $\mathrm{C}$ uptake is estimated from carbon fixation rate at $1 \mathrm{~m}$ depth and $\mathrm{N}$ uptake is the sum of nitrate and ammonium uptake measured at the same depth

\begin{tabular}{|c|c|c|c|c|c|c|}
\hline Mesocosm & & 22 May & 23 May & 24 May & 25 May & 26 May \\
\hline 5 & Control & 6.8 & 5.3 & 6.0 & 4.6 & 8.8 \\
\hline 1 & $16 \mathrm{~N}: 1 \mathrm{P}-$ low rate of addition & 9.5 & 6.5 & 8.1 & 9.5 & 14.1 \\
\hline 2 & $16 \mathrm{~N}: 1 \mathrm{P}-$ high rate of addition & 8.6 & 6.9 & 10.3 & 10.5 & 10.5 \\
\hline 8 & $1272 \mathrm{C}: 16 \mathrm{~N}: 1 \mathrm{P}-$ low rate of addition & 10.6 & 7.6 & 4.1 & 2.5 & 3.5 \\
\hline 9 & $1272 \mathrm{C}: 16 \mathrm{~N}: 1 \mathrm{P}$ - high rate of addition & 6.1 & 8.8 & 3.7 & 5.5 & 4.1 \\
\hline
\end{tabular}


Bioassays to determine if the bacterial assemblage was nutrient-limited were done by comparing ${ }^{3} \mathrm{H}$ leucine incorporation in the presence of various nutrient supplements. On Day 0, there was little stimulation
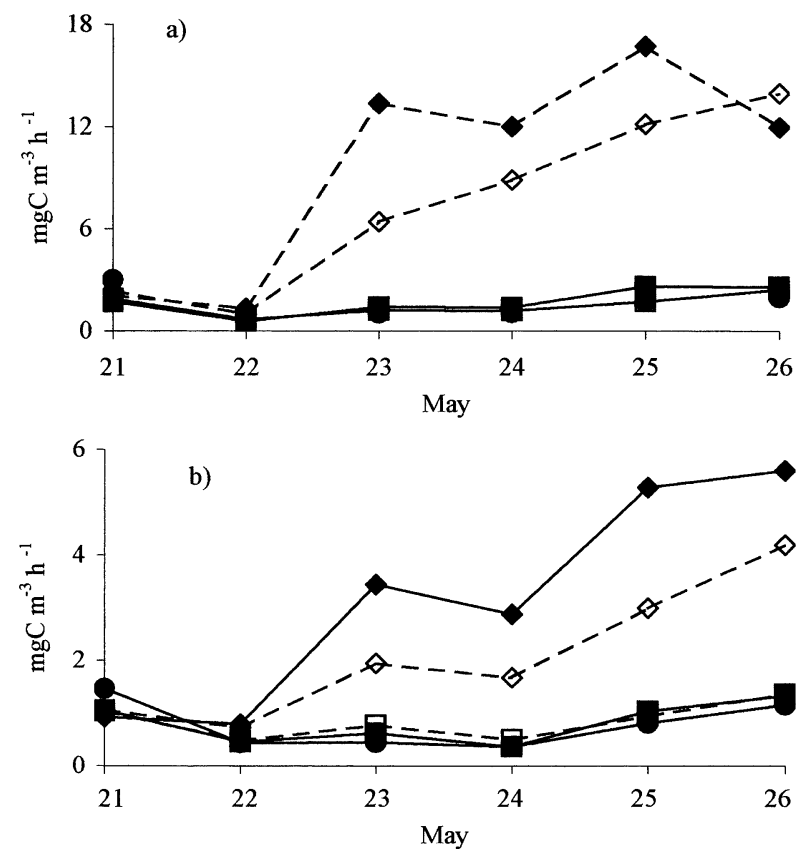

Fig. 9. Bacterial production estimated from the incorporation of (a) ${ }^{3} \mathrm{H}$ leucine and (b) ${ }^{3} \mathrm{H}$-thymidine in (•) Mesocosm 5 (control), () Mesocosm 1 with nitrate and phosphate additions at the lower rate, (घ) Mesocosm 2 with nitrate and phosphate additions at the higher rate, $(\diamond)$ Mesocosm 8 with nitrate, phosphate and glucose additions at the lower rate, and ( ) Mesocosm 9 with nitrate, phosphate and glucose additions at the higher rate

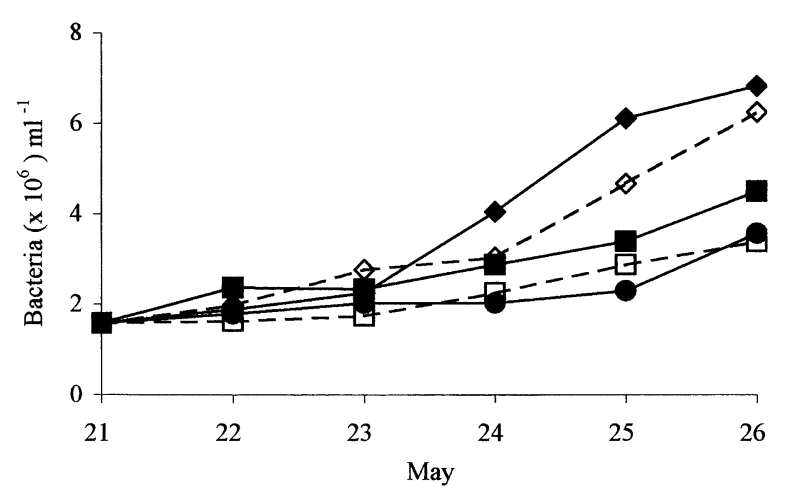

Fig. 10. Bacterial abundance epifluorescence counts in (•) Mesocosm 5 (control), () Mesocosm 1 with nitrate and phosphate additions at the lower rate, (匹) Mesocosm 2 with nitrate and phosphate additions at the higher rate, $(\diamond)$ Mesocosm 8 with nitrate, phosphate and glucose additions at the lower rate, and ( $\downarrow$ ) Mesocosm 9 with nitrate, phosphate and glucose additions at the higher rate

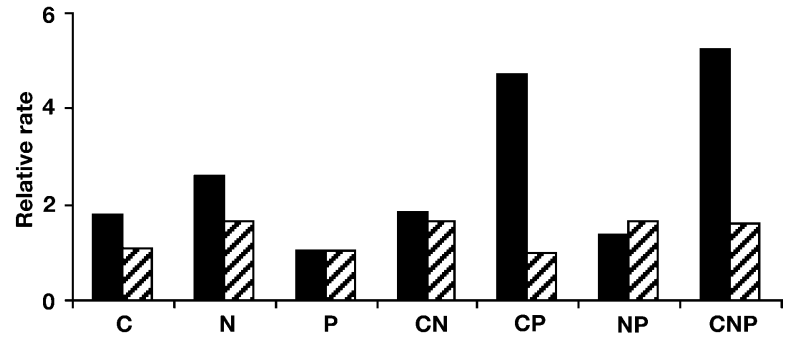

Fig. 11. Bioassays for factors limiting bacterial growth rate. C, $\mathrm{N}$ and $\mathrm{P}$ designates the addition of glucose, ammonia and phosphate to subsamples taken from the mesocosms. The response is measured as ${ }^{3} \mathrm{H}$ leucine uptake relative to leucine uptake in a control subsample without nutrient additions. The black bars indicate data at the beginning of the experiment on Day 0 and the striped bars on Day 3 from Mesocosm 9

(nitrate, phosphate and glucose added at the higher rate)

relative to unmodified samples of ${ }^{3} \mathrm{H}$ leucine uptake on the addition of $\mathrm{C}$ or $\mathrm{P}$ (Fig. 11). This suggests mixed $\mathrm{N}$ and $\mathrm{C}$ limitation of bacterial growth in this fjord. By Day 3, the response in Mesocosm 9, which was supplemented with N, P and glucose, showed less stimulation of added nutrient but indicated that $\mathrm{N}$ was the nutrient most likely to limit bacterial growth.

\section{DISCUSSION}

\section{Interactions between bacteria and phytoplankton}

The clearest result from these experiments is that both phytoplankton biomass and production were reduced in the presence of excess labile DOC. This occurred in replicate mesocosms to which glucose was added but did not occur in mesocosms which had the same additions of nitrate and phosphate, but no DOC supplement. Bacterial production and biomass was significantly enhanced in the mesocosms receiving glucose and inorganic nutrients, compared to those receiving $\mathrm{N}$ and $\mathrm{P}$ nutrients alone. Over the timespan of this experiment, we found no signs of major changes in biodiversity and population structure within the phytoplankton assemblage; however, significant changes occurred within the bacterial and viral communities (Øvreås et al. unpubl.).

There is some uncertainty about the dominant phytoplankton species indicated from the analysis of pigment composition (Fig. 5). The CHEMTAX calculation of the contribution of diatoms to the total chl a was clearly an overestimate when compared to microscopy of the starting assemblages. According to the CHEMTAX analysis, approximately $40 \%$ of the total chl a initially in the control bag was due to diatoms, while estimates of diatom carbon biomass from microscopy were 
less than $10 \%$ of the total biomass. This discrepancy probably results from the presence of other phytoplankton groups with pigment compositions similar to diatoms. For example, several flagellates (e.g. chrysophytes, raphidophytes and some haptophytes) contain fucoxanthin as the major carotenoid so it is not a unique indicator of diatoms (Jeffrey 1997).

There could be a number of reasons, both biological and physical, for the suppression of phytoplankton production. Changes in the light field are one obvious mechanism to reduce primary production in the presence of excess inorganic nutrient. Since the mesocosms received the same irradiance, any difference in light could only result from a change in light absorption within the water column. Specifically, the added glucose might have increased the bacterial biomass to such an extent that light attenuation was affected and the phytoplankton could have become light limited, resulting in reduced primary production. However, this possibility can be rejected. Table 3 shows the vertical attenuation coefficients $(k)$ measured in each mesocosm between 10:00 and 11:00 h on each day of the experiment and the $k$ values in Mesocosms 8 and 9 were not significantly different from those of the control or the other experimental mesocosms. Therefore, the changes in the heterotrophic assemblage which resulted from the addition of glucose did not affect light penetration and could not be the cause of the reduced primary production. Another factor which might result in a reduction in primary production would be the introduction of a contaminant. Since laboratory-grade glucose was used to make the labile DOC additions, this also seems very unlikely. Therefore, the most plausible explanation is that increased growth of heterotrophic bacteria shifted the assemblage structure.

There are 3 major ways in which higher bacterioplankton activity might influence phytoplankton: (1) as a result of increased competition for the available nutrients, phytoplankton might become nutrient limited, (2) increased bacterial production might stimulate an increase in predator numbers which could result in an increase in grazing pressure on phytoplankton; and
(3) the bacteria might directly influence the phytoplankton, i.e., the bacteria which grew in response to the added glucose might have been pathogenic, infecting the phytoplankton assemblage. Alternatively, as a result of the bacterial metabolism of glucose, secondary metabolites might be released which are inhibitory to phytoplankton. The first 2 hypotheses can be investigated with the data presented in this paper but no measurements were made which could address the possibility of bacterial pathogens or inhibitor production.

\section{Competition for nutrients}

The experimental addition of glucose- $\mathrm{C}$ relative to nitrate and phosphate additions, was much greater than the Redfield ratio, and the massive accumulation of DOC in Mesocosms 8 and 9 confirmed the expectation that the microbial system could not consume such a load of organic carbon. Although the glucose addition was a large increase of organic carbon to the mesocosms, the elevated nitrogen and phosphate might be expected to sustain high phytoplankton biomass; hence, leading to increased production of a range of organic substrates. This could be either directly by active or passive excretion, or indirectly by a secondary stimulation of predatory processes. If the interpretation is correct that growth rate of bacteria in Mesocosms 1 and 2 remained carbon limited, bacterial production in the 2 mesocosms would be directly related to the autochthonous production of labile DOC (assuming a constant carbon yield). Since only a minor stimulation of bacterial production was seen, we assume that there was no major release of labile DOC coupled directly to primary production or phytoplankton biomass in the assemblage investigated here.

The experimental design assumes that, with excess degradable organic carbon in Mesocosms 8 and 9, net heterotrophy would be expected. It is necessary to scale the supply of both autochthonous and allochthonous carbon to the different mesocosms. Table 4 compares the quantity of glucose added with the total

Table 3. Vertical attenuation coefficient $(k)$ of PAR $\left(\mathrm{m}^{-1}\right)$. nd: not determined

\begin{tabular}{|lccccc|}
\hline Date & Mesocosm 1 & Mesocosm 2 & Mesocosm 5 & Mesocosm 8 & Mesocosm 9 \\
\hline 21 May & 0.23 & 0.36 & 0.37 & 0.35 & 0.35 \\
22 May & nd & 0.42 & 0.35 & 0.35 & 0.38 \\
23 May & 0.31 & 0.31 & 0.31 & 0.35 & 0.34 \\
24 May & 0.35 & 0.36 & 0.35 & 0.35 & 0.31 \\
25 May & 0.33 & 0.37 & 0.41 & 0.42 & 0.38 \\
26 May & nd & 0.55 & & & 0.38 \\
\hline
\end{tabular}


Table 4. Supply of autochthonous and allochthonous organic carbon to each mesocosm calculated from the measured rates of depth-integrated primary production and volume of the mesocosms

\begin{tabular}{|c|c|c|c|c|c|c|c|}
\hline Mesocosm & 22 May & 23 May & $\begin{array}{l}24 \text { May } \\
\mathrm{g} \mathrm{C} \mathrm{m}^{-2} \mathrm{~d}\end{array}$ & 25 May & May 26 & $\begin{array}{l}\text { Total autochthonous } \\
\text { over experiment } \\
\text { (mmol C per mesocosm) }\end{array}$ & $\begin{array}{c}\text { Total allochthonous } \\
\text { (i.e. glucose added) } \\
\text { (mmol C per mesocosm) }\end{array}$ \\
\hline 1 & 158 & 247 & 192 & 177 & 270 & 154 & - \\
\hline 2 & 127 & 216 & 189 & 146 & 170 & 125 & - \\
\hline 5 & 124 & 133 & 86 & 83 & 168 & 88 & - \\
\hline 8 & 77 & 226 & 101 & 57 & 51 & 76 & 540 \\
\hline 9 & 84 & 204 & 78 & 72 & 61 & 74 & 1080 \\
\hline
\end{tabular}

organic carbon produced in each mesocosm by primary production. It should be emphasised that the autotrophic carbon production measurements do not include any estimates of DOC produced directly by phytoplankton excretion since the experiments only measured ${ }^{14} \mathrm{C}$ incorporation into material retained on $0.2 \mu \mathrm{m}$ pore size filters. However, as discussed above, we believe that this rate was small. It is obvious that the magnitude of carbon supply by primary production was small compared to that added to Mesocosms 8 and 9 as glucose (Table 4) - but the nature of the organic matter is also different. Glucose is biologically labile and is likely to be rapidly taken up by bacteria; the organic matter produced by primary production is new phytoplankton cells which are not necessarily directly available to heterotrophic bacteria that rely on dissolved substrates. Nevertheless, Mesocosms 8 and 9 clearly had excess labile DOC.

Additional information is given by the bioassays done with water from Mesocosm 9 on Day 3 (Fig. 11). These suggested that an excess of labile carbon, combined with $\mathrm{N}$ and $\mathrm{P}$ added in the Redfield ratio, led to $\mathrm{N}$-limitation of bacterial activity. This may indicate that the initial system in the fjord was more deficient in $\mathrm{N}$ than in P. However, adjusting the N:P ratio did not result in major changes in chl $a$, primary production, pigment composition, bacterial abundance or bacterial production (Mesocosms 3, 4, 6 and 7, data not shown), so the limitation may have been marginal.

The reduced phytoplankton biomass in the mesocosms with added glucose might be due to 2 processes, which are not mutually exclusive. The added glucose would have led to increased demand for inorganic nutrients by the bacteria and, with higher affinity for nutrients, bacteria were able to outcompete the phytoplankton assemblage. Alternatively, the increased bacterial production resulted in a simultaneous increase in microzooplankton predators which, in addition to grazing on bacteria, also grazed on the phytoplankton. The experimental evidence for each of these propositions is equivocal but is as follows.
Nitrate and ammonium uptake were measured by the incorporation of ${ }^{15} \mathrm{~N}$ substrates. Unlike the carbon uptake experiments, time and resources did not permit any size fractionation in these experiments. This is unfortunate because, if bacteria were responsible for increased nutrient uptake, there should have been elevated uptake in the $<2 \mu \mathrm{m}$ fraction. However, the data do indicate enhanced bacterial uptake-specifically there were changes in the $\mathrm{C}: \mathrm{N}$ uptake ratios (Table 2). Again, it is worth emphasising that the carbon uptake data used to calculate these $\mathrm{C}: \mathrm{N}$ ratios is only the carbon which is assimilated by the fixation of $\mathrm{CO}_{2}$ and do not include uptake of DOC. In autotroph-dominated systems, most of the $\mathrm{C}$ and $\mathrm{N}$ uptake is by phytoplankton and uptake ratios close to the Redfield ratio have been measured in a number of oceanic provinces (Rees et al. 1999, Donald et al. 2001). In the control mesocosm (Mesocosm 5) and Mesocosms 1 and 2, the C:N uptake ratio was close to the Redfield ratio and is consistent with rapid phytoplankton growth. In Mesocosms 8 and 9, the C:N uptake ratio declined after $2 \mathrm{~d}$ and these low ratios suggest increased bacterial demand for inorganic nitrogen. Inorganic nitrogen is required by heterotrophic bacteria when the nitrogen content of the organic matter source is low (Joint \& Morris 1992). In this case, if the added glucose stimulated bacterial production and was transformed into biomass, the bacteria would require nitrogen. The low $\mathrm{C}: \mathrm{N}$ uptake ratios are strong evidence that the bacterial demand for nitrate and ammonium was significantly greater in Mesocosms 8 and 9 than in the other experiments.

Nitrogen was added in the form of nitrate, which may not be available to all bacteria. Indeed, Kirchman (1994) has suggested that nitrate is the nitrogen source of last resort to bacteria in the oligotrophic oceans; this may not necessarily apply to coastal oceans where nitrate concentrations tend to be much greater. Many bacteria lack nitrate reductase and there is a higher energetic cost of utilising nitrate, rather than ammonium or dissolved organic nitrogen. For photoautotrophs, the energetics of nitrate reduction do not pre- 
sent much of a problem since the energy is derived from light but for heterotrophs, nitrate reduction requires additional catabolism of organic substrates. In these experiments, although nitrate was added to the mesocosms as nitrogen source, ammonium uptake was usually more important. Table 5 shows $f$-ratios, that is the ratio of nitrate uptake to the uptake of ammonium and nitrate, for each ${ }^{15} \mathrm{~N}$ uptake experiment. All $f$ ratios are low, indicating that these systems did not depend on nitrate as the primary nitrogen source. This raises the question of what was the source of the ammonium?

Nitrate did not accumulate in most of the mesocosms (Fig. 1a) (although there were linear increases in Mesocosms 2 and 8); therefore, it must have been used by the biota - but the ${ }^{15} \mathrm{~N}$ experiments do not indicate high rates of nitrate uptake. There was some increase in ammonium concentration (Fig. 1b), which was probably produced by heterotrophic activity. Since nitrate uptake is low, it is unlikely that the ammonium is released from cells which were utilising nitrate but it is probable that the ammonium is derived from the mineralisation of organic nitrogen already in the water column when the mesocosms were filled. Mineralisation of that organic nitrogen appeared to be supplying ammonium at sufficient rate to limit nitrate uptake. Why then did the addition of nitrate to Mesocosms 1 and 2 result in an increase in phytoplankton production and biomass? Since ammonium was the preferred nitrogen source for phytoplankton in these assemblages (Fig. 8), it is possible that it was phosphate, added at the same time as the nitrate, which was responsible for the increase in phytoplankton. In general, the phosphorus load to Danish estuaries has been reduced significantly over the last decade (Conley et al. 2000) and in several fjords, phosphate-limited phytoplankton assemblages are found for a high proportion of the growth season (Holmboe et al. 1999). Measurements at a monitoring station in Isefjorden revealed phosphate concentrations below $0.2 \mu \mathrm{mol} \mathrm{l}^{-1}$, indicating potential phosphorus limitation (Fischer et al. 1992) from March through June 2000 (Strømberg \& Angartyr 2001). Thus, it is possible that the enclosed phytoplankton assemblages were phosphorus limited. Unfortunately, no measurements of phosphate uptake were made to confirm this speculation.

\section{Other controls on biomass}

Predation is the second mechanism which might result in lower phytoplankton biomass when glucose was added. If added glucose increased bacterial biomass, which in turn resulted in an increase in microzooplankton numbers, that grazing pressure might
Table $5 .{ }^{15} \mathrm{~N}$-based determinations of the $f$-ratio, demonstrating the relative importance of nitrate and ammonium as nitrogen source

\begin{tabular}{|lccccc|}
\hline Mesocosm & 22 May & 23 May & 24 May & 25 May & 26 May \\
\hline 1 & 0.34 & 0.59 & 0.23 & 0.23 & 0.42 \\
2 & 0.23 & 0.27 & 0.20 & 0.09 & 0.14 \\
5 & 0.31 & 0.47 & 0.36 & 0.24 & 0.38 \\
8 & 0.26 & 0.66 & 0.71 & 0.44 & 0.53 \\
9 & 0.21 & 0.39 & 0.28 & 0.18 & 0.26 \\
\hline
\end{tabular}

also reduce the phytoplankton biomass. Flagellates are assumed to be the primary grazers on bacteria; the flagellates in turn are grazed by ciliates, which also graze on phytoplankton. The generation time of flagellates is short - of the same order as bacteria - so it is possible that their abundance would change rapidly in response to the increased bacterial production. Ciliates have longer generation times and there would be a delay of several days before ciliate grazing could begin to impact on flagellate numbers. If this description of the interactions within the microbial assemblage is correct, then some of the assumptions are testable by the experimental data.

If flagellate grazing pressure increased rapidly, they presumably grazed on picophytoplankton as well as on bacterioplankton. The size-fractionated chl a concentrations (Fig. 3) show that the biomass of picophytoplankton did decline after Day 4 and was significantly less than in the comparable system without added glucose (Mesocosm 1). This supports the hypothesis of increased grazing on all organisms $<2 \mu \mathrm{m}$. However, the biomass of phytoplankton cells $10-2 \mu \mathrm{m}$ and $>10 \mu \mathrm{m}$ showed no increase in the mesocosms supplied with glucose. This would result if there was tight grazing control on these size fractions. But why did the biomass of $<2 \mu \mathrm{m}$ phytoplankton increase in Mesocosms 1 and 2 if there was close coupling between primary production and grazing? This implies that microzooplankton grazing was not able to control increases in phytoplankton of all cell sizes when nutrients were added, but that grazing control could have been exerted when glucose stimulated bacterial activity.

Virus infection is the third mechanism which might control biodiversity. In this experiment, an indication of viral diversity of the mesocosm was obtained by pulse field gel electrophoresis (PFGE). Øvreås et al. (unpubl.) found little change in the number of PFGE fingerprint bands in the control mesocosm throughout the experiment and little change in the mesocosms to which nitrate and phosphate were added. However, the most profound changes occurred in Mesocosms 8 and 9 to which excess glucose was added. Bacteria biodiversity, as assessed by denaturing gradient gel elec- 
trophoresis (DGGE) and fluorescent in situ hybridisation (FISH) also showed greatest change in bacterial biodiversity in these 2 treatments with the dominance of a few species of Vibrio. The changes appeared to be linked and there was a close to 1:1 ratio in the numbers of DGGE and PFGE bands (Øvreås et al. unpubl.). Therefore, there is circumstantial evidence that changes in viruses occurred at the same time as changes in bacterial biodiversity and this may have been important in influencing system function. However, we do not have detailed information on the total number of viruses nor do we know if specific viruses responded to the dominance of Vibrio in Mesocosms 8 and 9. It does appear that the growth of Vibrio was not significantly limited by virus infection over the $6 \mathrm{~d}$ of the experiment.

The most likely explanation for these changes in biomass, both of bacteria and of different size fractions of phytoplankton, is a complex interaction between grazing and nutrient limitation of phytoplankton by bacteria whose activity increased greatly in the presence of labile DOC.

Acknowledgements. This work is partly funded by the European Union in the framework of the Mast 3 Programme, contract number MAS3-CT97-0154 (MIDAS project) and by the Plymouth Marine Laboratory, which is a collaborative centre of the Natural Environment Research Council. We thank Andy Rees for mass spectrometric analysis of the ${ }^{15} \mathrm{~N}$ samples. We wish to acknowledge the invaluable assistance give to us by Winnie Martinsen during the experiments in Holbæk, Denmark in May 2000.

\section{LITERATURE CITED}

Baretta-Bekker JG, Baretta JW, Hansen AS, Riemann B (1998) An improved model of carbon and nutrient dynamics in the microbial food web in marine mesocosms. Aquat Microb Ecol 14:91-108

Bergh Ø, Børsheim KY, Bratbak G, Heldal M (1989) High abundance of viruses found in aquatic environments. Nature 340:467-468

Brewer PG, Riley JP (1965) The automatic determination of nitrate in seawater. Deep-Sea Res 12:765-772

Brussaard CPD, Riegman R (1998) Influence of bacteria on phytoplankton cell mortality with phosphorus or nitrogen as the algal-growth-limiting nutrient. Aquat Microbial Ecol 14:271-280

Conley DJ, Kaas H, Møhlenberg F, Rasmussen B, Windolf J (2000) Characteristics of Danish estuaries. Estuaries 23: 820-837

Donald KM, Joint I, Rees AP, Woodward EMS, Savidge G (2001) Uptake of carbon, nitrogen and phosphorus by phytoplankton along the $20^{\circ} \mathrm{W}$ meridian the NE Atlantic between $56.5^{\circ} \mathrm{N}$ and $37^{\circ} \mathrm{N}$. Deep-Sea Res II 48:873-897

Dugdale RC, Goering JJ (1967) Uptake of new and regenerated forms of nitrogen in primary productivity. Limnol Oceanogr 12:196-206

Edler L (1979) Recommendations on methods to marine biological studies in the Baltic Sea. Phytoplankton and chlorophyll. Baltic Mar Biol Publ 5:38
Egge JK (1998) Are diatoms poor competitors at low phosphate concentrations? J Mar Syst 16:191-198

Fischer TR, Peele ER, Ammerman JW, Harding LW (1992) Nutrient limitation of phytoplankton in Chesapeake Bay. Mar Ecol Prog Ser 82:51-63

Grasshoff K (1976) Methods of seawater analysis. Verlag Chemie, Weinheim

Gustavson K, Petersen S, Pedersen B, Stuer-Lauridsen F, Pedersen S, Wangberg SA (1999) Pollution-Induced Community Tolerance (PICT) in coastal phytoplankton communities exposure to copper. Hydrobiologia 416:125-138

Hein M, Riemann B (1995) Nutrient limitation of phytoplankton biomass or growth-rate - an experimental approach using marine mesocosms. J Exp Mar Biol Ecol 188: 167-180

Henriksen P, Riemann B, Kaas H, Sørensen HM, Sørensen HL (2002) Effects of nutrient-limitation and irradiance on marine phytoplankton pigments. J Plankton Res 24:in press

Holmboe N, Jensen HS, Andersen FØ (1999) Nutrient addition bioassays as indicators of nutrient limitation of phytoplankton in an eutrophic estuary. Mar Ecol Prog Ser 186: 95-104

Holm-Hansen O, Lorenzen CJ, Holmes RW, Strickland JDH (1965) Fluorometric determination of chlorophyll. J Cons Perm Int Explor Mer 30:3-15

IOC (1994) Protocols for the Joint Global Ocean Flux Study (JGOFS) core measurements. Manuals Guides IOC 29, Paris

Jeffrey SW (1997) Application of pigment methods to oceanography. In: Jeffrey SW, Mantoura RFC, Wright SW (eds) Phytoplankton pigments in oceanography. UNESCO Publishing, Paris, p 127-166

Joint IR, Morris RJ (1982) The role of bacteria in the turnover of organic matter in the sea. Oceanogr Mar Biol Annu Rev 20:65-118

Joint IR, Pomroy AJ (1983) Production of picoplankton and small nanoplankton in the Celtic Sea. Mar Biol 77:19-27

Kirchman DL (1994) The uptake of inorganic nutrients by heterotrophic bacteria. Microbial Ecol 28:255-271

Kirchman DL, K'Nees E, Hodson R (1985) Leucine incorporation and its potential as measure of protein synthesis by bacteria in natural aquatic samples. Appl Environ Microbiol 49:599-607

Mackey MD, Mackey DJ, Higgins HW, Wright SW (1996) CHEMTAX - a program for estimating class abundances from chemical markers: application to HPLC measurements of phytoplankton. Mar Ecol Prog Ser 144:265-283

Mantoura RFC, Woodward EMS (1983) Optimisation of the indophenol blue method for the automated determination of ammonia in estuarine waters. Estuar Coast Shelf Sci 17: $219-224$

Mullin JB, Riley JP (1966) The colorimetric determination of silicate with special reference to sea and natural waters. Anal Chim Acta 12:162-176

Owens NJP, Rees AP (1989) Determination of nitrogen-15 at submicrogram levels of nitrogen using automated continuous-flow isotope ratio mass spectrometry. Analyst 114: 1655-1657

Parsons TR, Albright LJ, Whitney F, Wong CS, Williams PJL (1981) The effect of glucose on the productivity of seawater: an experimental approach using controlled aquatic ecosystems. Mar Environ Res 4:229-242

Platt T, Rao DVS, Irwin B (1983) Photosynthesis of picoplankton in the oligotrophic ocean. Nature 301:702-704

Porter KG, Feig YS (1980) Use of DAPI for identifying and counting aquatic microflora. Limnol Oceanogr 25:943-948 
Proctor LM, Fuhrman JA (1990) Viral mortality of marine bacteria and cyanobacteria. Nature 343:60-62

Redfield AC, Ketchum BH, Richards FA (1963) The influence of organisms on the composition of sea water. In: Hill MN (ed) The sea, Vol 2. Wiley-Liss, New York, p 26-77

Rees AP, Joint I, Donald KM (1999) Early spring bloom phytoplankton-nutrient dynamics at the Celtic Sea Shelf Break. Deep-Sea Res I 46:483-510

Riemann B, Bjørnsen PK, Newell S, Fallon, R (1987) Calculation of cell production of coastal marine bacteria based on measured incorporation of $\left[{ }^{3} \mathrm{H}\right]$-thymidine. Limnol Oceanogr 32:471-476

Ryther J (1969) Photosynthesis and fish production in the sea. The production of organic matter and its conversion to higher forms of life throughout the world ocean. Science 166:72-76

Schlüter L, Havskum H (1997). Phytoplankton pigments in relation to carbon content in phytoplankton communities. Mar Ecol Prog Ser 155:55-65

Shiah FK, Ducklow HW (1995) Regulation of bacterial abundance and production by substrate supply and bacterivory - a mesocosm study. Microb Ecol 30:239-255

Simon M, Azam F (1989). Protein content and protein synthesis rates of planktonic marine bacteria. Mar Ecol Prog Ser 51:201-213

Sondergaard M, Williams PJL, Cauwet G, Riemann B, Robinson C, Terzic S, Woodward EMS, Worm J (2000) Net accumulation and flux of dissolved organic carbon and dissolved organic nitrogen in marine plankton communities. Limnol Oceanogr 45:1097-1111

Smith DC, Azam F (1992) A simple economical method for

Editorial responsibility: John Dolan,

Villefrance-sur-Mer, France measuring bacterial protein synthesis in sea water using ${ }^{3}$ H-leucine. Mar Microb Food Webs 6:107-114

Strickland JDH, Parsons TR (1968) A practical handbook of seawater analysis. Bull Fish Res Board Can 167, Ottawa

Strømberg J, Angantyr LA (2001) Vandmiljø Overvågning NOVA 2003-Isefjord 2000. Vestsjællands Amt, Sorø, p 33 (in Danish)

Taylor AH, Joint I (1990) A steady state analysis of the 'microbial loop' in stratified systems. Mar Ecol Prog Ser 59:1-17

Thingstad TF, Lignell R (1997) Theoretical models for the control of bacterial growth rate, abundance, diversity and carbon demand. Aquat Microbial Ecol 13:19-27

Thingstad TF, Havskum H, Kaas H, Lefevre D, Nielsen TG, Riemann B, Williams PJL (1999a) Bacteria-protist interactions and organic matter degradation under P-limited conditions: comparison between an mesocosm experiment and a simple model. Limnol Oceanogr 44:62-79

Thingstad TF, Pérez M, Pelegri S, Dolan J, Rassoulzadegan F (1999b) Trophic control of bacterial growth in microcosms containing a natural community from northwest Mediterranean surface waters. Aquat Microb Ecol 18:145-156

Utermöhl H (1958) Zur Vervollkommung der quantitativen phytoplankton-methodik. Mitt Int Ver Theor Angew Limnol 9:1-38

Wilson WH, Mann NH (1997) Lysogenic and lytic viral production in marine microbial communities. Aquat Microbial Ecol 13:95-100

Wright SW, Jeffrey SW, Mantoura RFC, Llewellyn CA, Bjornland T, Repeta D, Welschmeyer N (1991) Improved HPLC method for the analysis of chlorophylls and carotenoids from marine phytoplankton. Mar Ecol Prog Ser 77:183-196

Submitted: January 7, 2002; Accepted: May 21, 2002

Proofs received from author(s): September 2, 2002 